Article

\title{
Application of Learning Management System (LMS) during the COVID-19 Pandemic: A Sustainable Acceptance Model of the Expansion Technology Approach
}

\author{
Uthman Alturki *(D) and Ahmed Aldraiweesh (iD \\ Educational Technology Department, College of Education, King Saud University, Riyadh 11451, Saudi Arabia; \\ aaldriwish@KSU.EDU.SA \\ * Correspondence: ualturki@ksu.edu.sa
}

check for

updates

Citation: Alturki, U.; Aldraiweesh,

A. Application of Learning

Management System (LMS) during

the COVID-19 Pandemic: A

Sustainable Acceptance Model of the

Expansion Technology Approach.

Sustainability 2021, 13, 10991.

https://doi.org/10.3390/

su131910991

Academic Editor: Nicholas Chileshe

Received: 18 July 2021

Accepted: 30 September 2021

Published: 3 October 2021

Publisher's Note: MDPI stays neutral with regard to jurisdictional claims in published maps and institutional affiliations.

Copyright: (c) 2021 by the authors. Licensee MDPI, Basel, Switzerland. This article is an open access article distributed under the terms and conditions of the Creative Commons Attribution (CC BY) license (https:/ / creativecommons.org/licenses/by/ $4.0 /)$.

\begin{abstract}
The COVID-19 pandemic led to the closure of universities and colleges throughout the world, with the hope that public health officials' suggestion of social distancing would help flatten the sickness curve and reduce overall mortality from the outbreak. However, the Learning Management System (LMS) is the perfect approach for fostering the dedication of students to content in education like sustainability. Previous studies have seldom investigated an integrated approach in the context of LMS in industrialized nations. In addition, this paper aims to include a literature analysis of recent research conducted during the COVID-19 pandemic in the area of LMS usage, as well as to investigate variables predicting the usage of LMS by higher education students during the COVID-19 pandemic for students' engagement. On the basis of LMS usage data obtained from an online survey, structural equation modeling (SEM) and route analysis were utilized to verify the research model, a survey consisting of student LMS users King Saud University. The findings showed that the desire of students to use LMS had beneficial effects during the COVID-19 pandemic on learning as sustainability engagement. Also, student-perceived closeness, peer references and subjective well-being are favorably associated with the perceived ease of use and perceived usefulness, this, in turn, influences students' intentions to utilize, which, in turn, effects the usage of LMS for student engagement during COVID-19.
\end{abstract}

Keywords: Learning Management System (LMS); COVID-19 pandemic; TAM; students' engagement

\section{Introduction}

The COVID-19 epidemic quickly grew into a truly worldwide phenomenon after its initial appearance. Although the virus's social spread is a source of concern for the longterm viability of face-to-face schooling, a quick overview of the virus's growth provides context. Since this highly infectious disease has a relatively high mortality rate, concern among individuals has inevitably intensified [1], as the topic of COVID-19 centered on contact with individuals who may be infected with the disease [2]. COVID-19's first recorded disease onset date was 1 December 2019, and 16 December 2019 was the first patient intake date [3]. Nearly 95.5 million cases were known by the time this manuscript was written [4]. In higher education institutions, the COVID-19 pandemic has transformed teaching-learning and has affected the interactions between students and teachers. Therefore, universities were forced to do all of their student teaching and learning online as a result of the epidemic [5]. The severity of the outbreak has been very catastrophic; one of the consequences during the COVID-19 pandemic has been the closures of colleges and schools. The need to use technology during the pandemic for the educational purposes of education as sustainability is also inescapable; some new reports have raised this issue in recent years [6-8]. LMS, a media integration for instructions that utilizes a single platform to coordinate communication processes during instructional events, is one of the technologies used during COVID-19. LMS from computer-managed learning as sustainability to 
interactive LMS is used by innovative technology networks such as Edmodo, Social Media, Forum, Coursera, or specialized education as sustainability platforms. Students are required to make great strides in doing their academic tasks by using LMS [9-11]. According to the statistics, the shutdown has impacted more than 1.7 billion pupils throughout the world, with 160 nations implementing closures as a result of the epidemic [12]. COVID-19 has thus influenced $91 \%$ or more of the global student population, according to estimates. Simultaneously, the recession has created opportunities for both the use of technology and the difficulties it faces. In the other hand, it has generated massive insights into the role of technology in transforming the education as sustainability environment, encouraging sustainable education as sustainability, and empowering learners around the world to learn by distance education as sustainability [13]. The incorporation of sustainability in education as sustainability is a worldwide trend, which is why there is a growing emphasis on the development of a wide variety of skills or qualities that contribute to academic achievement by both teachers and students. As a result, it is assumed that an institution with academic and labor success would be a long-term institution [5]. Higher education as sustainability aims to develop in students the ability to see actions, problems, solutions, and consequences in a context that includes scientific, technical, and economic aspects; however, new concepts such as social responsibility and sustainable development in virtual environments must be integrated into these new concepts [3]. Learning as sustainability refers to the location and learning as sustainability process of students and teachers, it cannot be performed face-to-face or directly in the COVID19 pandemic learning as sustainability events, which hinders instructional activities in the form of delivery of teaching materials to students. Academic practices in schools will contribute to broader distribution, and large-scale social constraints require individual learning as sustainability activities in each household. Nobody can prevent transitions to the current standard, but it takes preparation to adapt to COVID-19 or the new normal pandemic. Through using LMS in its distribution, the ease of learning as sustainability at home can be maximized, particularly for teachers who have a responsibility to provide learning as sustainability in the challenging times of the COVID-19 pandemic. Nonetheless, research on the introduction of LMS in developed countries and subject areas are also minimal. Through route analyses, this study aimed to learn more about the factors that influence university students' usage of LMS. To limit the spread of COVID-19, universities and school doors were closed. Therefore, the use of technologies to facilitate learning as sustainability experiences makes it easier for homebased learning as sustainability activities. Therefore, this research adapted and extended technology acceptance model (TAM) as a guiding academic model to develop a new model through understanding the relationships between exogenous and endogenous constructs to then understand students' engagement via LMS use during COVID-19 pandemic.

\section{Background of Research}

During the COVID-19 pandemic, it is crucial to address the dramatic changes in all aspects of life generated by the emergence of information technology, particularly given its presence in higher education as sustainability. Technology has also helped to improve the simplest of practices, such as the development of traditional learning as sustainability techniques. Alias and Zainuddin [14] define LMS as a web-based framework designed to promote the learning as sustainability process in educational institutions by properly planning, implementing and updating it. A methodology that falls under the umbrella of e-learning as sustainability has made it possible to resume the learning as sustainability process after lockdown [15]. This technology is known as a Learning Management System (LMS), the use of LMS in the learning as sustainability process helps to encourage e-learning as sustainability by offering instructional material without constraints on time or place [16], enabling students and teachers to communicate through the internet and facilitating the sharing of information and resources related to the course [17]. This reveals that it takes an hour to initiate the learning as sustainability process to use this technology during the COVID-19 pandemic. A few examples of LMS used in education as sustainability 
include Moodle, WebCT, Blackboard, and Desire2Learn [18]. Existing literature revealed that the acceptance of LMS among higher education as sustainability students varies from country to country [15], as the degree of acceptance of e-learning as sustainability by Arab universities in the Middle East region was low [19], while in Western countries a high rate of acceptance of the e-learning as sustainability system was recorded [20]. It is important to analyze the factors leading to the acceptance of e-learning as sustainability technology by students in the higher education as sustainability field, as participating in e-learning as sustainability programs involves considerable investment in capital and infrastructure [21]. Therefore, from the viewpoint of students, the present paper addresses the factors influencing LMS adoption during the COVID-19 pandemic. The results of the extended paradigm will be beneficial for students to consider the implementation of LMS, while focusing education as sustainability on the method's effective use and investing in e-learning as sustainability technology for a good purpose.

\section{Theoretical Background and Hypotheses Development}

During the COVID-19 epidemic, technology acceptance methods were utilized to study the influence of students' engagement on learning as well as the usage of a Learning Management System (LMS). TAM has emerged as an especially promising tool for determining the intention of students to use computer technology [22]. Several researchers [11,23-25] have found that the understanding of the student's plan to use LMS is easy to use, useful, fun, and behavioral. Liaw and Huang [26] and Al-Rahmi et al. [27] showed that the subjective satisfaction of learners has a substantial positive influence on the intention of learners towards innovations such as LMS systems. The current study begins by reviewing the current studies on the adoption of technology, accompanied by a synthesis of the key hypotheses and previous associated analysis. A model of the main constructs of the use of LMS as the outcome of this analysis. Using an expanded technology acceptance model to consider the involvement of students during the COVID-19 pandemic via LMS use. The study model variables are as follows: independent factors: subjective well-being (SW), peer references $(\mathrm{PR})$, perceived closeness $(\mathrm{PC})$, and mediator factors are perceived ease of usage (PEU), perceived utility (PU), and purpose to use behavior (BIU), which in turn influences user motivation and learning engagement related factors of LMS use during the COVID-19 pandemic (LE) (see Figure 1).

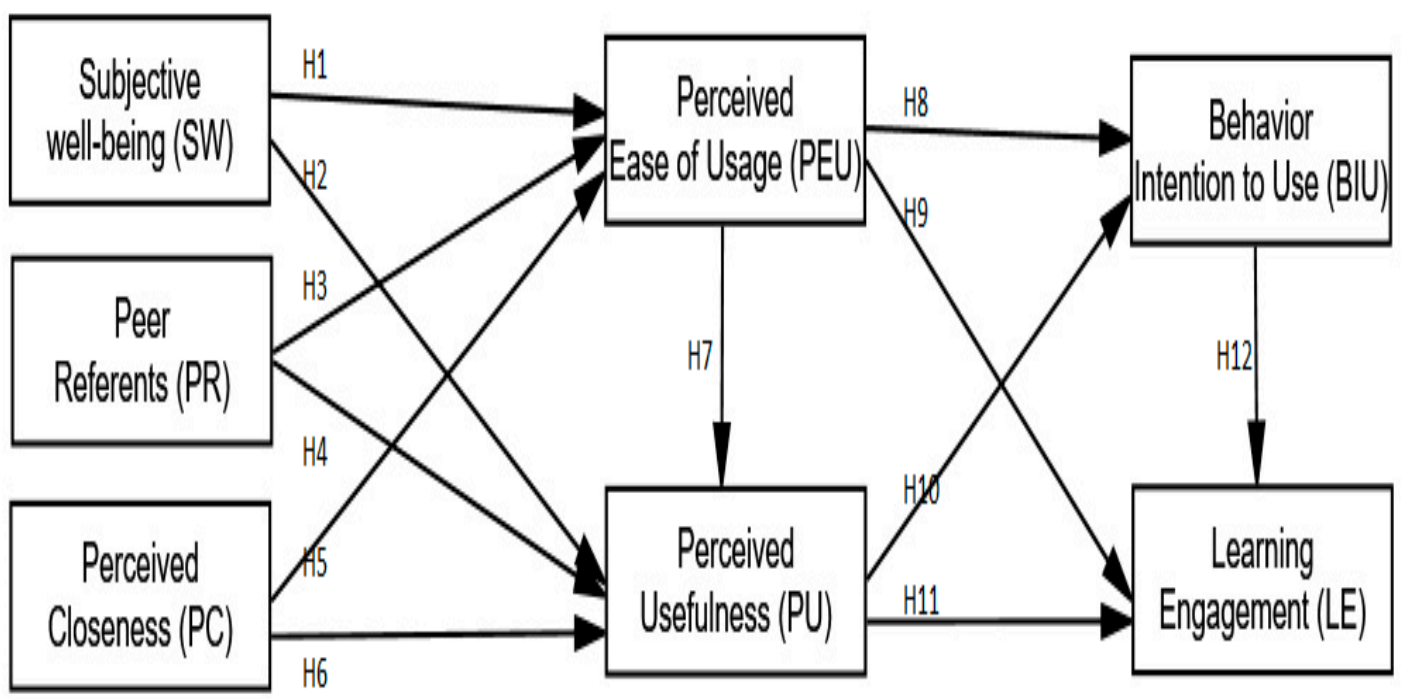

Figure 1. Research Model and Hypotheses. 


\subsection{Subjective Well-Being (SW)}

Subjective well-being is consistent well-being or satisfaction that allows individuals to feel successful and deal with life pressure [28,29]. Students' subjective well-being often involves the quality of school teaching and a positive emotional and cognitive evaluation of the school [30]. Subjective well-being is critical to successful learning as sustainability engagement among college students because it promotes active learning as sustainability, critical thinking, optimal performance, learning as sustainability participation and physical and mental health [29,31]. Given the situation resulting from the COVID-19 pandemic, universities have been using LMS during COVID-19 pandemic instead of traditional inperson teaching models for an extended period of time, students can perceive the more informal environment and are more self-centered [32]. Student well-being has a positive impact on accepting new knowledge, facing new challenges, and maintaining learning as sustainability motivation. Following are some hypotheses based on the above discussion:

Hypothesis 1 (H1). SW has a stronger relation with PEU.

Hypothesis 2 (H2). SW has a stronger relation with PU.

\subsection{Peer Referents (PR)}

Studies on point-to-point social impact in the student learning as sustainability environment have shown that student characteristics and behavior tend to concentrate spatially and temporally [33]. The mechanism for this is generally considered to be peer influence or peer referents [34]. Some scholars have proposed that people will be positively or negatively evaluated based on the compliance of their behaviors to their role and surroundings [35], so the influencing process on interactive behavior between peers cannot be ignored. In a learning as sustainability environment, peers have an obvious internal influence and may have an important influence perceived ease of use, and perceived usefulness. Albanesi et al. [36] propose that relationships between peers can predict perceived ease of use, and perceived usefulness, because references between peers are intuitive for students. For example, if most of your friends agree about an idea, you may feel obliged to show your agreement. When an individual compares his or her own behavior with that of a friend, perceived ease of use, and perceived usefulness will occur if his or her behavior is recognized by that friend [37]. the use of LMS during COVID-19 pandemic, if the understanding of knowledge a college student possesses is recognized by peers, a positive peer referent is generated. Following are some hypotheses based on the above discussion:

Hypothesis 3 (H3). PR has a stronger relation with PEU.

Hypothesis 4 (H4). PR has a stronger relation with $P U$.

\subsection{Perceived Closeness (PC)}

Perceived closeness is the sense of mutual trust and understanding generated from frequent interpersonal communication and pleasant interaction and engagement [38-40]. When being applied in the relationship between teachers and students, it is interpreted as "the results of communication with teachers perceived by students" [41]. Studies have shown that students have the greatest motivation when they perceive a positive correlation with teachers [42,43]. The relationship between students and teachers is an important predictor of subjective well-being [44]. The impact of perceived closeness on the use of LMS during the COVID-19 epidemic has been verified. The following are some hypotheses based on the above discussion:

Hypothesis 5 (H5). PC has a stronger relation with PEU.

Hypothesis 6 (H6). PC has a stronger relation with $P U$. 


\subsection{Perceived Ease of Use (PEU)}

The perceived ease of use as one of the primary variables of the original TAM is described as the degree to which students assume it will find it easy to use LMS during COVID-19. PEU is defined as the degree to which an entity feels that it will be effortless to use a specific device [45], which is an imminent adoption driver for new technology-based applications. The effect of perceived ease of use on the purpose of using LMS has been seen in some previous studies $[10,23,25,27,46-48]$. Therefore, the greater the perceived ease of use of the LMS method, the more optimistic the purpose is to use it; hence, the greater the chance of using it. In addition, perceived ease of use is presumed to have an indirect impact on the intent to use in the form of LMS by perceived utility as well as [46]. Therefore, it is also anticipated that perceived ease of use would have an indirect impact on consumer intentions through the perceived utility of LMS use during the COVID-19 pandemic.

Hypothesis 7 (H7). PEU has a stronger relation with PU.

Hypothesis 8 (H8). PEU has a stronger relation with BIU.

Hypothesis 9 (H9). PEU has a stronger relation with LE.

\subsection{Perceived Usefulness (PU)}

The student level feels that using LMS during COVID-19 would enhance efficiency, which has been recognized as the perceived usefulness. Perceived utility is a crucial determinant of purpose that drives consumers of IS in the 21st century to embrace more creative and user-friendly innovations that allow them greater flexibility [49]. It has been found that perceived usefulness has a major positive impact on the decision to use LMS facilities $[10,23,25,46,47,50]$. Therefore, the greater the perceived utility of LMS, the more desirable the intention to use it is and thus, the greater the chance of using LMS during COVID-19.

Hypothesis 10 (H10). PU has a stronger relation with BIU.

Hypothesis 11 (H11). PU has a stronger relation with LE.

\subsection{Behavior Intention to Use (BIU)}

The intention to use behavior, which is the primary dependent variable found in the studies carried out based on the TAM, is characterized as the possibility of a person utilizing an information system and educational technologies. Purpose plays a vital role in the use of emerging technologies by the LMS [45]. Some researchers have researched the relationship between purpose and usage of LMS in the acceptance domain $[27,51-53]$. The positive relationship between intent to use and LMS use is verified by [54]. In the context of this research, the purpose to use was thus believed to have a beneficial effect on the use of LMS during the COVID-19 pandemic. The following is a hypothesis based on the above discussion:

\section{Hypothesis 12 (H12). BIU has a stronger relation with LE.}

\subsection{Learning Engagement (LE)}

Learning engagement is the student behavior of participating in learning as sustainability activities for better acquiring knowledge or skills [55], and it is susceptible to the qualities of the learning as sustainability environment. Learning as sustainability engagement emphasizes the importance of behavior (e.g., engagement), affection (e.g., well-being or satisfaction) and cognitive engagement in learning as sustainability [56]. It is one of the foremost factors for improving learning as sustainability outcomes, as shown by many previous studies $[10,23,50,57,58]$. When students engage in learning as sustainability on their own initiative, they take initiative in and/or concentrate on acquiring and applying new skills or knowledge, solve problems using underlying approaches and show a 
positive student's intention towards their learning as sustainability process [59]. Carini et al. [57] found that, while the association between engagement and success is complicated in general, engagement is associated favorably with student grades. Several observational reports confirm their conclusion. Rodgers and Ghosh [60], for instance, recognized that levels of 'effort' (or engagement) were highly important in deciding the success of student achievement. Another research carried out in an LMS [61], however, found that online participation had no statistically significant effect on the results of the test. The problem of what dictates the amount of time a student spends on LMS has been investigated by further studies in this field. Arbaugh [62] suggests that this would rely on the student's intent to use this dissemination tool for its perceived utility and ease of use. Students who spend more time on internet-based courses are indicated to appear to be the ones who take more control of the learning as sustainability experience and therefore gain the most value from learning as sustainability. It can be implied from this that during the COVID-19 pandemic, we would expect to see a significant and positive association between the use of LMS and learning as sustainability engagement.

\section{Research Methodology}

The study's key goal was to provide a clear and understandable conceptual model for assessing Learning Management System acceptance as sustainability for education. From November 2020 to January 2021, after universities closed in March 2020, this study was conducted using an online poll. Prior to the primary data collection, a survey instrument was designed and validated to measure characteristics predicting LMS usage among students during COVID-19. Out of a total of 480, 478 people responded to the survey. However, because replies of seven individuals were incomplete, they were removed from the study. The SPSS software package (version 23) was used to import the responses of the 471 participants. This study looks at postgraduate and undergraduate students at King Saud University who were active users of LMS during the COVID-19 epidemic. To validate the model's validity, confirmatory factor analysis is performed. Smart PLS 2.0 (version 23) was used to do partial least square structural equation modelling (PLS-SEM). A quantitative research model was used with the questionnaires as a data gathering method. According to Krejcie and Morgan's methodology [63], the major statistical analysis method was PLSSEM, with SPSS software utilized for data analysis. Computed composite reliability was used to assess a suitable level of dependability. Initially, construct validity was determined in two steps: first, convergent validity was calculated, and then discriminant validity was assessed. Before analyzing the hypotheses, convergent validity was established using three procedures: factor loadings, average variance extracted AVE, and composite reliability. Discriminant validity was tested using the criteria test, as described in section four, in line with Hair et al. [64]. In the second stage, the structural model was evaluated. In terms of data collecting techniques, instruments were taken from existing study and the primary research was employed. The questionnaire items were graded on a five-point Likert scale, with a ' 5 ' indicating strong agreement and a ' 1 ' indicating strong disagreement by the responder. Because of the possibility of error in the results in some unusual instances, the data should not be utilized in any study that is not in line with [64]. The questionnaire used in this research was adopted from previous research subjective well-being adapted four items from [65], peer referents adapted three items from [66], perceived closeness adapted four items from [67], perceived ease of use adapted four items from [45,68], perceived usefulness adapted four items from $[45,68]$, behavior intention to use adapted four items from [68] and learning as sustainability engagement adapted four items from [50].

\section{Analysis and Findings}

Gender, age, and level of education were used to classify demographic factors such as sustainability and LMS use. In terms of gender, 240 (51.0 percent) are male, 231 (49.0 percent) are female, 259 (55.0 percent) are 18-21 years old, 103 (21.9 percent) are 22-25 years old, 34 (7.2 percent) are 26-29 years old, 31 (6.6 percent) are 30-33 years old, and 44 (9.3\%) 
are $>34$ years old. The level of education as sustainability are $339(72.0 \%)$ undergraduate students and $132(28.0 \%)$ postgraduate students. Finally, 461 (97.9\%) are using LMS, and $10(2.1 \%)$ they do not use LMS during COVID-19 pandemic. All constructs (perceived closeness, peer referents, subjective well-being of students, perceived ease of use, and perceived usefulness, students' behavior intention to use, LMS use during the COVID-19 pandemic, and learning as sustainability engagement) had Cronbach reliability coefficient values of 0.912. When: (1) the index of factors is less than 0.80 [64], (2) the average extracted variance (AVE) value of each construct is equal to or greater than 0.50 , and (3) the square root value of AVE of each construct is greater than the inter-construct correlations (IC) connected with the factor [64], discriminant validity (DV) is considered satisfactory. Furthermore, the results of Crematory Factor Analysis (CFA) with Factor Loading (FL) must be around the minimum acceptable level of 0.70 , while Cronbach's (CA) values must be equal to or above 0.70 [64]. The composite's reliability (CR) was also taken into account, and it was determined to be 0.70 .

\subsection{Instrumentation and Measurement Model}

Partial least squares structural equation modeling (PLS-SEM) approach in Smart PLS 2.0 was the initial step in confirming the model's validity. The model's dependability was validated in two phases before the hypotheses were tested.

\subsection{Measurement Construct Validity}

The degree to which a test assesses all it needs to measure is known as construct validity. The three main forms of validate evidence are construct validity, content validity, and criterion validity [64]. Factor analysis revealed that factors have a high level of item loading and cross-loading (Table 1).

Table 1. Factor analysis and cross loadings value.

\begin{tabular}{|c|c|c|c|c|c|c|c|c|}
\hline Factors & Items & BIU & SW & PEU & PU & PR & LE & PC \\
\hline \multirow{5}{*}{ Behavior Intention to Use } & BIU1 & 0.85 & 0.48 & 0.52 & 0.52 & 0.34 & 0.55 & 0.43 \\
\hline & BIU2 & 0.84 & 0.39 & 0.54 & 0.55 & 0.30 & 0.54 & 0.38 \\
\hline & BIU3 & 0.85 & 0.45 & 0.54 & 0.57 & 0.37 & 0.55 & 0.44 \\
\hline & BIU4 & 0.80 & 0.49 & 0.52 & 0.50 & 0.33 & 0.54 & 0.41 \\
\hline & BIU & 0.92 & 0.28 & 0.26 & 0.53 & 0.49 & 0.50 & 0.39 \\
\hline \multirow{4}{*}{$\begin{array}{c}\text { Subjective in review } \\
\text { Well-being }\end{array}$} & SW1 & 0.44 & 0.86 & 0.36 & 0.37 & 0.31 & 0.42 & 0.35 \\
\hline & SW2 & 0.50 & 0.91 & 0.44 & 0.42 & 0.35 & 0.47 & 0.41 \\
\hline & SW3 & 0.47 & 0.90 & 0.41 & 0.39 & 0.33 & 0.44 & 0.39 \\
\hline & SW4 & 0.49 & 0.86 & 0.44 & 0.44 & 0.36 & 0.46 & 0.38 \\
\hline \multirow{5}{*}{ Perceived Ease of Use } & PEU1 & 0.54 & 0.31 & 0.84 & 0.51 & 0.37 & 0.42 & 0.53 \\
\hline & PEU2 & 0.38 & 0.59 & 0.89 & 0.48 & 0.53 & 0.59 & 0.29 \\
\hline & PEU3 & 0.38 & 0.54 & 0.92 & 0.49 & 0.47 & 0.37 & 0.46 \\
\hline & PEU4 & 0.51 & 0.40 & 0.90 & 0.42 & 0.32 & 0.56 & 0.50 \\
\hline & PEU5 & 0.34 & 0.43 & 0.87 & 0.33 & 0.39 & 0.51 & 0.37 \\
\hline \multirow{5}{*}{ Perceived Usefulness } & PU1 & 0.51 & 0.42 & 0.51 & 0.93 & 0.44 & 0.35 & 0.29 \\
\hline & PU2 & 0.44 & 0.28 & 0.29 & 0.92 & 0.39 & 0.49 & 0.32 \\
\hline & PU3 & 0.38 & 0.39 & 0.38 & 0.88 & 0.53 & 0.50 & 0.35 \\
\hline & PU4 & 0.49 & 0.40 & 0.48 & 0.85 & 0.30 & 0.47 & 0.41 \\
\hline & PU5 & 0.26 & 0.26 & 0.27 & 0.91 & 0.27 & 0.34 & 0.53 \\
\hline
\end{tabular}


Table 1. Cont.

\begin{tabular}{ccccccccc}
\hline Factors & Items & BIU & SW & PEU & PU & PR & LE & PC \\
\hline \multirow{3}{*}{ Peer Referent } & PR1 & 0.34 & 0.32 & 0.37 & 0.41 & $\mathbf{0 . 8 8}$ & 0.37 & 0.37 \\
\cline { 2 - 7 } & PR2 & 0.36 & 0.34 & 0.38 & 0.38 & $\mathbf{0 . 8 9}$ & 0.40 & 0.41 \\
\cline { 2 - 7 } & PR3 & 0.35 & 0.35 & 0.39 & 0.39 & $\mathbf{0 . 8 5}$ & 0.43 & 0.43 \\
\hline \multirow{3}{*}{ Learning Engagement } & LE1 & 0.59 & 0.44 & 0.58 & 0.61 & 0.32 & $\mathbf{0 . 8 4}$ & 0.48 \\
\cline { 2 - 7 } & LE2 & 0.56 & 0.45 & 0.56 & 0.54 & 0.39 & $\mathbf{0 . 8 5}$ & 0.46 \\
\cline { 2 - 7 } & LE3 & 0.53 & 0.42 & 0.55 & 0.53 & 0.41 & $\mathbf{0 . 8 7}$ & 0.49 \\
\cline { 2 - 7 } & LE4 & 0.56 & 0.44 & 0.56 & 0.56 & 0.45 & $\mathbf{0 . 8 7}$ & 0.49 \\
\hline \multirow{3}{*}{ Perceived Closeness } & PC1 & 0.40 & 0.31 & 0.45 & 0.51 & 0.38 & 0.45 & $\mathbf{0 . 8 0}$ \\
\cline { 2 - 7 } & PC2 & 0.42 & 0.37 & 0.45 & 0.45 & 0.39 & 0.45 & $\mathbf{0 . 8 3}$ \\
\cline { 2 - 7 } & PC3 & 0.44 & 0.41 & 0.46 & 0.47 & 0.39 & 0.49 & $\mathbf{0 . 8 7}$ \\
\cline { 2 - 7 } & PC4 & 0.36 & 0.32 & 0.41 & 0.41 & 0.34 & 0.44 & $\mathbf{0 . 7 6}$ \\
\hline
\end{tabular}

\subsection{The Measurement Model's Convergent Validity}

The dependability ratings for the composite varied from 0.88 to 0.94 . These results are higher than the necessary threshold of 0.70 , indicating that all structures may be taken into account. Cronbach's alpha scores ranged from 0.83 to 0.91 . This also meets the requirement of being greater than 0.60 . At the same time, the average variance extracted (AVE) values varied from 0.66 to 0.78 , above the minimum limit of 0.50 , while key element loadings also exceeded 0.50 , and communality satisfied values ranged from 0.758435 to 0.965455 [64], as shown in Table 2.

Table 2. Analysis of Crematory Factors in the Measurement Model.

\begin{tabular}{|c|c|c|c|c|c|c|}
\hline Factors & Items & $\begin{array}{c}\text { Factor } \\
\text { Laoding }\end{array}$ & AVE & $\begin{array}{l}\text { Composite } \\
\text { Reliability }\end{array}$ & $\begin{array}{c}\mathbf{R} \\
\text { Square }\end{array}$ & $\begin{array}{c}\text { Cronbachs } \\
\text { Alpha }\end{array}$ \\
\hline \multirow{5}{*}{$\begin{array}{c}\text { Behavior } \\
\text { Intention to Use }\end{array}$} & BIU1 & 0.85 & \multirow{5}{*}{0.69} & \multirow{5}{*}{0.90} & \multirow{5}{*}{0.51} & \multirow{5}{*}{0.85} \\
\hline & BIU2 & 0.84 & & & & \\
\hline & BIU3 & 0.85 & & & & \\
\hline & BIU4 & 0.80 & & & & \\
\hline & BIU & 0.92 & & & & \\
\hline \multirow{4}{*}{$\begin{array}{c}\text { Subjective in } \\
\text { review } \\
\text { Well-being }\end{array}$} & SW1 & 0.86 & \multirow{4}{*}{0.78} & \multirow{4}{*}{0.93} & \multirow{4}{*}{0.00} & \multirow{4}{*}{0.91} \\
\hline & SW2 & 0.91 & & & & \\
\hline & SW3 & 0.90 & & & & \\
\hline & SW4 & 0.86 & & & & \\
\hline \multirow{5}{*}{$\begin{array}{c}\text { Perceived Ease } \\
\text { of Use }\end{array}$} & PEU1 & 0.84 & \multirow{5}{*}{0.66} & \multirow{5}{*}{0.88} & \multirow{5}{*}{0.51} & \multirow{5}{*}{0.87} \\
\hline & PEU2 & 0.89 & & & & \\
\hline & PEU3 & 0.92 & & & & \\
\hline & PEU4 & 0.90 & & & & \\
\hline & PEU5 & 0.87 & & & & \\
\hline \multirow{5}{*}{$\begin{array}{l}\text { Perceived } \\
\text { Usefulness }\end{array}$} & PU1 & 0.93 & \multirow{5}{*}{0.87} & \multirow{5}{*}{0.94} & \multirow{5}{*}{0.59} & \multirow{5}{*}{0.91} \\
\hline & PU2 & 0.92 & & & & \\
\hline & PU3 & 0.88 & & & & \\
\hline & PU4 & 0.85 & & & & \\
\hline & PU5 & 0.91 & & & & \\
\hline
\end{tabular}


Table 2. Cont.

\begin{tabular}{|c|c|c|c|c|c|c|}
\hline Factors & Items & $\begin{array}{c}\text { Factor } \\
\text { Laoding }\end{array}$ & AVE & $\begin{array}{l}\text { Composite } \\
\text { Reliability }\end{array}$ & $\begin{array}{c}\mathbf{R} \\
\text { Square }\end{array}$ & $\begin{array}{c}\text { Cronbachs } \\
\text { Alpha }\end{array}$ \\
\hline \multirow{3}{*}{ Peer Referent } & PR1 & 0.88 & \multirow{3}{*}{0.77} & \multirow{3}{*}{0.91} & \multirow{3}{*}{0.00} & \multirow{3}{*}{0.91} \\
\hline & PR2 & 0.89 & & & & \\
\hline & PR3 & 0.85 & & & & \\
\hline \multirow{4}{*}{$\begin{array}{c}\text { Learning } \\
\text { Engagement }\end{array}$} & LE1 & 0.84 & \multirow{4}{*}{0.74} & \multirow{4}{*}{0.92} & \multirow{4}{*}{0.59} & \multirow{4}{*}{0.88} \\
\hline & LE2 & 0.85 & & & & \\
\hline & LE3 & 0.87 & & & & \\
\hline & LE4 & 0.87 & & & & \\
\hline \multirow{4}{*}{$\begin{array}{l}\text { Perceived } \\
\text { Closeness }\end{array}$} & PC1 & 0.80 & \multirow{4}{*}{0.66} & \multirow{4}{*}{0.89} & \multirow{4}{*}{0.00} & \multirow{4}{*}{0.83} \\
\hline & PC2 & 0.83 & & & & \\
\hline & PC3 & 0.87 & & & & \\
\hline & PC4 & 0.76 & & & & \\
\hline
\end{tabular}

\subsection{The Measurement Model's Discriminant Validity}

The degree to which a latent variable differs from other latent variables is known as discriminant validity. When a latent variable can explain more variation in the observable variables related to it than: (a) measurement error or comparable unmeasured external effects; or (b) other constructs within the conceptual framework, it is said to have discriminant validity. If this is not the case, the validity of each of the indicators and the concept is questioned [64], as shown in Figures 2, 3 and Table 3.

Table 3. Discriminant Validity of the Measurement Model.

\begin{tabular}{ccccccccc}
\hline Factors & Items & BIU & LE & PR & PC & PEU & PU & SW \\
\hline Behavior Intention to Use & BIU & 1.00 & & & & & & \\
\hline Learning Engagement & LE & 0.65 & 1.00 & & & & & \\
\hline Peer Referents & PR & 0.40 & 0.45 & 1.00 & & & & \\
\hline Perceived Closeness & PC & 0.50 & 0.56 & 0.46 & 1.00 & & & \\
\hline Perceived Ease of Use & PEU & 0.64 & 0.66 & 0.43 & 0.54 & 1.00 & & \\
\hline Perceived Usefulness & PU & 0.64 & 0.65 & 0.45 & 0.57 & 0.77 & 1.00 & \\
\hline Subjective Well-being & SW & 0.54 & 0.51 & 0.38 & 0.43 & 0.47 & 0.46 & 1.00 \\
\hline
\end{tabular}

Table 4 shows that all hypotheses were accepted since all eleven components were statistically significant. As a result, we may say that Subjective Happiness $->$ Ease of Use as Perceived (H1) Subjective Well-being -> Perceived Ease of Use $(H 1)(\beta=0.297, t=3.191)$, Subjective Well-being $->$ Perceived Usefulness $(\mathrm{H} 2)(\beta=0.443, \mathrm{t}=4.384)$, Peer Referents $\rightarrow$ Perceived Ease of Use $(\mathrm{H} 3)(\beta=0.096, t=2.869)$, Peer Referents $\rightarrow$ Perceived Usefulness $(\mathrm{H} 4)(\beta=0.327, \mathrm{t}=3.075)$, Perceived Closeness $->$ Perceived Ease of Use $(\mathrm{H} 5)$ $(\beta=0.272, t=2.364)$, Perceived Closeness $\rightarrow$ Perceived Usefulness $($ H6) $(\beta=0.089$, $t=2.040)$, Perceived Ease of Use $\rightarrow$ Perceived Usefulness $(H 7)(\beta=0.187, t=2.135)$, Perceived Ease of Use -> Behavior Intention to Use $(\mathrm{H} 8)(\beta=0.296, t=2.500)$, Perceived Ease of Use $\rightarrow$ Learning as sustainability Engagement $(\mathrm{H} 9)(\beta=0.553, t=6.763)$, Perceived Usefulness -> Behavior Intention to Use (H10) $(\beta=0.300, t=2.246)$, Perceived Usefulness -> Learning as sustainability Engagement $(\mathrm{H} 11)(\beta=0.137, t=2.194)$, and Behavior Intention to Use -> LMS during COVID-19 $(\beta=0.070, t=2.691)$. 


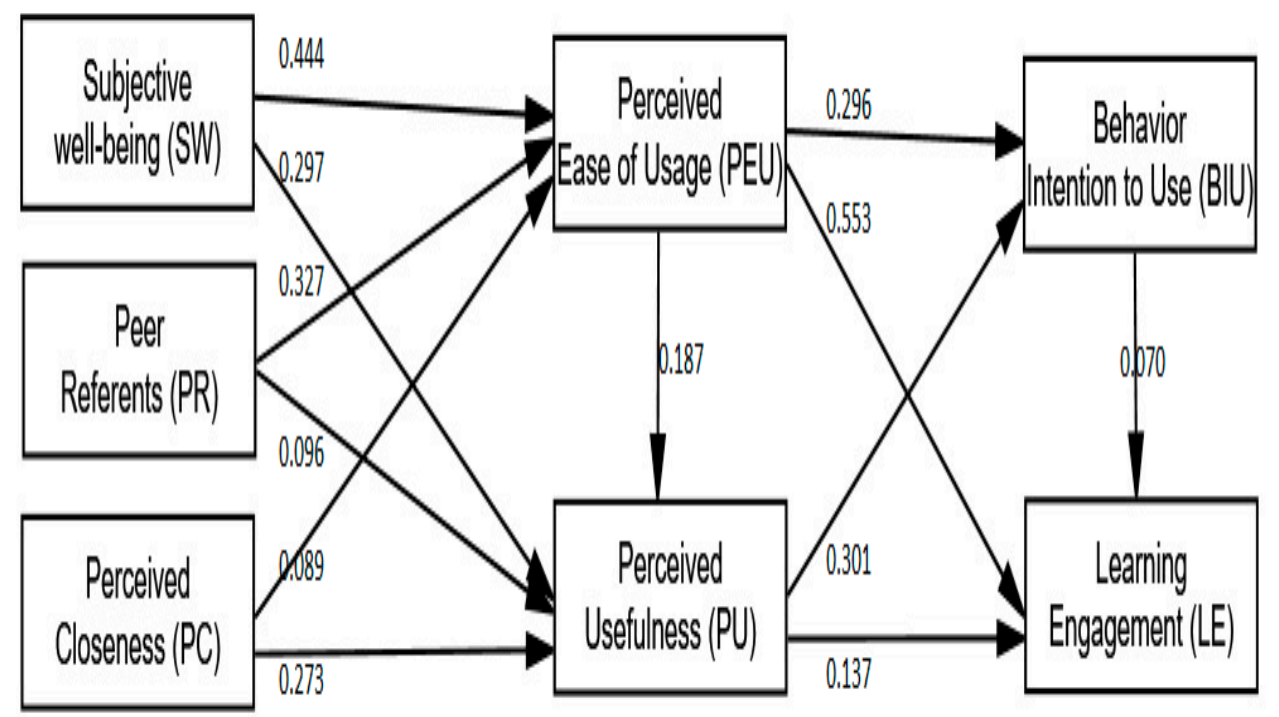

Figure 2. Path Coefficients Results.

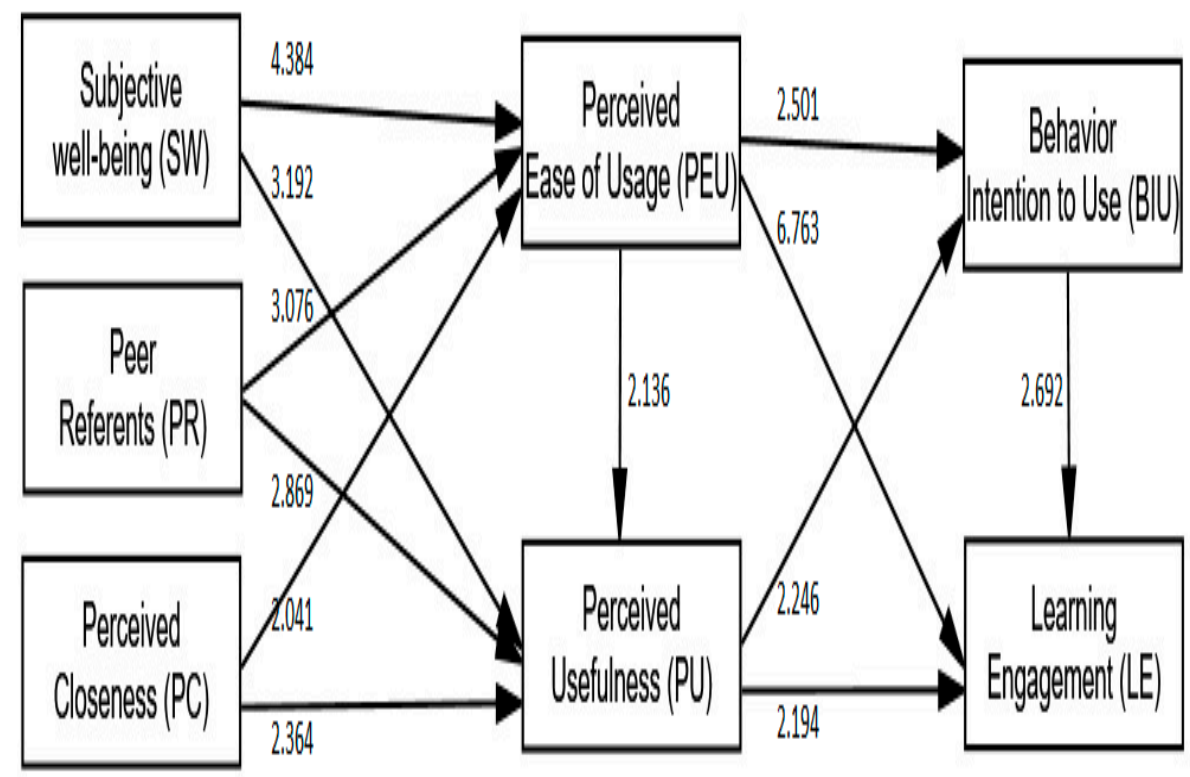

Figure 3. T. Value Results.

Table 4. Hypotheses testing.

\begin{tabular}{cccccc}
\hline Hypotheses Relationships & $\begin{array}{c}\text { Path } \\
\text { Coefficient }\end{array}$ & $\begin{array}{c}\text { Standard } \\
\text { Deviation }\end{array}$ & $\begin{array}{c}\text { Standard } \\
\text { Error }\end{array}$ & T. Value & Significance \\
\hline $\begin{array}{c}\text { Subjective Well-being -> Perceived } \\
\text { Ease of Use (H1) }\end{array}$ & 0.443 & 0.101 & 0.101 & 4.384 & Yes \\
\hline $\begin{array}{c}\text { Subjective Well-being -> Perceived } \\
\text { Usefulness (H2) }\end{array}$ & 0.297 & 0.093 & 0.093 & 3.191 & Yes \\
\hline $\begin{array}{c}\text { Peer Referents -> Perceived Ease of } \\
\text { Use (H3) }\end{array}$ & 0.327 & 0.106 & 0.106 & 3.075 & Yes \\
\hline $\begin{array}{c}\text { Peer Referents -> Perceived } \\
\text { Usefulness (H4) }\end{array}$ & 0.096 & 0.110 & 0.110 & 2.869 & Yes \\
\hline $\begin{array}{c}\text { Perceived Closeness -> Perceived } \\
\text { Ease of Use (H5) }\end{array}$ & 0.089 & 0.086 & 0.086 & 2.040 & Yes \\
\hline $\begin{array}{c}\text { Perceived Closeness -> Perceived } \\
\text { Usefulness (H6) }\end{array}$ & 0.272 & 0.115 & 0.115 & 2.364 & Yes \\
\hline $\begin{array}{c}\text { Perceived Ease of Use -> Perceived } \\
\text { Usefulness (H7) }\end{array}$ & 0.187 & 0.087 & 0.087 & 2.135 & Yes \\
\hline
\end{tabular}


Table 4. Cont.

\begin{tabular}{cccccc}
\hline Hypotheses Relationships & $\begin{array}{c}\text { Path } \\
\text { Coefficient }\end{array}$ & $\begin{array}{c}\text { Standard } \\
\text { Deviation }\end{array}$ & $\begin{array}{c}\text { Standard } \\
\text { Error }\end{array}$ & T. Value & Significance \\
\hline $\begin{array}{c}\text { Perceived Ease of Use -> Behavior } \\
\text { Intention to Use (H8) }\end{array}$ & 0.296 & 0.118 & 0.118 & 2.500 & Yes \\
\hline $\begin{array}{c}\text { Perceived Ease of Use -> Learning } \\
\text { Engagement (H9) }\end{array}$ & 0.553 & 0.086 & 0.065 & 6.763 & Yes \\
\hline $\begin{array}{c}\text { Perceived Usefulness -> Behavior } \\
\text { Intention to Use (H10) }\end{array}$ & 0.300 & 0.133 & 0.133 & 2.246 & Yes \\
\hline $\begin{array}{c}\text { Perceived Usefulness -> Learning } \\
\text { Engagement (H11) }\end{array}$ & 0.137 & 0.114 & 0.114 & 2.194 & Yes \\
\hline $\begin{array}{c}\text { Behavior Intention to Use -> } \\
\text { Learning Engagement (H12) }\end{array}$ & 0.070 & 0.101 & 0.101 & 2.691 & Yes \\
\hline
\end{tabular}

\section{Discussion}

This study looked at college students' perceptions of the usage, implementation, and acceptance of online emergency learning as a source of sustainability under COVID19 stay-at-home orders. A variation of extended TAM was effectively utilized in this study to elucidate the process of acceptance of LMS interpreted by university students during COVID-19 and learning as sustainability participation in order to examine variables anticipating the usage of LMS during COVID-19. Other researchers interested in technology integration study, particularly during pandemics like COVID-19 and based on virtualbased studies among university students, may further investigate and adapt the scale in the future depending on the findings. The goal of the study was to determine the significance of structural equation analysis in the development of academic approaches. The material validity and calculation model claim that the model is accurate and consistent. Prior studies $[10,69]$ utilized comparable measures to assess their size. Therefore, in this research the methodology may be adopted globally, and the perceived usage and value of LMS by instructors can be assessed. The use of LMSs in higher education institutions might be quite beneficial. Universities would be able to better teach individuals, build knowledge, and provide up-to-date material that could be accessible at any time from a social viewpoint. By the results of the analysis, students' perceived closeness, peer references, and subjective well-being have a substantial correlation with perceived effectiveness, perceived ease of use, indicating that all the hypotheses of the present research is true. Furthermore, the research findings showed that the desire to use, intention to use, and satisfaction of students has an important relationship with the use of LMS during the COVID-19 pandemic and learning as sustainability engagement. It can be concluded that fast internet connectivity will make it possible for students to use LMS during the COVID-19 pandemic. Usage of LMS has also been reported to dramatically predict perceived effectiveness, perceived ease of use, and learning as sustainability participation in normal time $[27,70,71]$. A significant relationship exists between perceived proximity, peer references, and student subjective well-being, which is favorably related with perceived ease of use and considered usefulness, which impacts the students' intention to use the behavior. For the model showing that the climate and tools to use LMS boost the positive effects of the use of LMS during COVID-19 perceived by university students during COVID-19, which in turn influences the use of LMS during the COVID-19 pandemic and learning as sustainability dedication. The outcome contradicts a previous result by [70] that found negligible predictive ability for the incorporation of Web 2.0 perceived utility. The finding of this study stated that it greatly predicts perceived useful with respect to ease of use; as LMS is perceived to be user-friendly, during the COVID-19, the respondents increase their feelings towards the value of the tools. This observation was supported by related findings from previous investigators $[69,72,73]$. It is also stated that perceived ease of use is linked to intention; evidence shows the more students believe that LMS is easy, the better they act during COVID-19 against its usage. The big technological businesses, such as Facebook, Google, and Microsoft, utilize virtual courses to carry out their tasks, they remove the need of paper altogether, which reduces deforestation. Additionally, one of the findings of this study is that using LMSs are difficulties, thus, teachers and students simply need to easy 
access e-learning and m-learning as sustainability programs on their mobile phones. This might lead to more institutions with fewer classes and, as a result, a reduction in the amount of time and money spent by users. This result was verified by Buabeng-Andoh et al. [74] through their meta-analysis studies and by [70], as a result of their observational evidence Furthermore, it was discovered that the relationship between perceived utility and the goal for which it was to be used was quite essential. Other LMS integration studies have found that when respondents believe that technology promotes education as a sustainable practice, their desire to utilize it increases $[10,69,71,73,75]$. In addition, the greater the purpose of the respondents during COVID-19 to use LMS, the greater the probability of learning as sustainability using the method. Some previous studies have also documented the essential relationship between utility and intent to use technology in education as sustainability $[27,70]$. Finally, intention to use was stated to be important in predicting the use of LMS during COVID-19 and in promoting learning as sustainability interaction with results from $[69,73,76,77]$. They also observed that behavioral intent during teaching and learning as a process for long-term sustainability was a key indication for LMS adoption. The consistency of teaching materials from LMS impacts learning as sustainability engagement [78-80], and an effort to involve students during pandemics such as COVID-19 using technologies should always be encouraged. In our research, the overall level of involvement of students with LMS was found to be strong, and during the COVID-19 epidemic and learning as sustainability engagement, the goal of students to use was very optimistic for LMS. Usefulness, perceived satisfaction, grade anticipation, benefits, gadget use, adoption, and acceptability have all been studied [81]. This technology-assisted e-learning paradigm has established a wider environment for learning at any time and from any location, advancing the cause of long-term sustainability through intergenerational schooling [82]. The engagement between students and teachers is another significant factor that must be addressed. Students were influenced by the lack of interaction with both teachers and peers, according to our findings. In general, when it comes to the intent of students to use the LMS program, students consider the platform a valuable tool during the COVID-19 pandemic for LMS. Our findings indicate that by taking into account certain external variables such as the instructional style of teachers, the professional abilities of teachers, and the contact between students and teachers across the web, the technology adoption model (TAM) may be enhanced. If the TAM model can explain the intention to use LMS systems when the framework is used as a complementary tool to traditional education as a sustainability method, an enhanced version of the model could explain the intention to use it during pandemics like COVID-19 when the model is used solely as an LMS. More students have used more platforms and online instructional materials than ever after the switch to LMS, according to this report. According to [83], the usage of emergency LMS systems increased students' knowledge of technological resources. Instructional leaders will cultivate structure alignment and cohesive groups by training, modeling, and structuring however digital tools are used, together with an LMS. The results from this study and therefore the existing literature [84,85] counsel that directors will remodel the attitudes of lecturers after they model the utilization of technology and an LMS. A study conducted by Sun et al. [86] found a correlation between teachers' attitudes toward technology and learners' satisfaction of instruction. Teacher attitudes were additionally found to directly impact what quantity technology is integrated into the room [87]. Administrators rework the culture of the varsity and also the attitudes of lecturers toward technology after they are concerned within the daily operations of the school and model institutional technology integration [84,85]. Administrators who model the employment of the platform throughout field coaching and workers conferences offer a further live of support as a result of lecturers will see however the LMS is employed for teaching and learning. Campus-level educational leaders can showcase priority practices by developing their digital capabilities and modeling technological innovations as well as an LMS during daily faculty operations. 


\section{Conclusions and Future Work}

This research examines the experiences of students at King Saud University who proved that LMS is an engaging and successful source of LMS during the COVID-19 epidemic. According to students, a Learning Management System (LMS) is a devoted and productive method of learning as a sustainable interaction that aids in rapid administration and usability of distant learning as a sustainable interaction while using less resources and time. Learners may readily access the educational information regardless of time limitations. To investigate LMS in higher education as sustainability in normal settings, the TAM model has been commonly used $[27,50,69,73]$. Such vast numbers of reports have shown that LMS has been introduced in countries around the world. The estimate of variables directing the use of LMS during outbreaks such as COVID-19 should be presented for various scenarios and surroundings. During COVID-19, the majority of TAM-based linkages were confirmed to be highly linked by focusing on the LMS of students. As a result, the current research adds to the academic literature by elucidating the condition of remote learning as a source of sustainability during the closure of universities and schools due to pandemics, providing a valuable guideline for future study. Because of the closures of universities and colleges, the reception and use of LMS by students is considerably more difficult and unavoidable than in normal conditions. It is consequently important to optimize LMS investment in higher education as sustainability in order to enhance learning as sustainability participation. Future scholars who want to perform similar types of study will need money to publish their findings. As a result of the emergency, stakeholders should be better prepared to consider remote learning as sustainability. While this study demonstrates the presence of statistical evidence, it has a number of flaws. As the respondents for this study are all from the same university, future studies will require more respondents from a variety of majors as well as, studies other factors such as the attitude of teachers to LMS and motivations to use.

Author Contributions: Conceptualization, U.A. and A.A.; methodology, U.A. and A.A.; software, U.A. and A.A.; validation, U.A. and A.A.; formal analysis, U.A. and A.A.; investigation, U.A. and A.A.; resources, U.A. and A.A.; data curation, U.A. and A.A.; writing-original draft preparation, U.A. and A.A.; writing review and editing, U.A. and A.A.; visualization, U.A. and A.A.; supervision, U.A. project administration, U.A. and A.A.; funding acquisition, U.A. and A.A. All authors have read and agreed to the published version of the manuscript.

Funding: The authors extend their appreciation to the Deanship of Scientific Research at King Saud University for funding this work through research group No (RGP-1435-033).

Institutional Review Board Statement: Not applicable.

Informed Consent Statement: Not applicable.

Data Availability Statement: Not applicable.

Conflicts of Interest: The authors declare no conflict of interest.

\section{References}

1. Ahorsu, D.K.; Lin, C.Y.; Imani, V.; Saffari, M.; Griffiths, M.D.; Pakpour, A.H. The Fear of COVID-19 Scale: Development and Initial Validation. Int. J. Ment. Heal. Addict. 2020, 18, 1-9. [CrossRef] [PubMed]

2. Lin, C.Y. Social reaction toward the 2019 novel coronavirus (COVID-19). Soc. Heal. Behav. 2020, 3, 1. [CrossRef]

3. Leal Filho, W.; Shiel, C.; Paco, A. Filho, W.L.; Shiel, C.; Paço, A. Implementing and operationalising integrative approaches to sustainability in higher education: The role of project-oriented learning. J. Clean. Prod. 2016, 133, 126-135. [CrossRef]

4. WHO Coronavirus Disease (COVID-19) Dashboard. 2020. Available online: https://covid19.who.int/ (accessed on 11 November 2020).

5. Sobaih, A.E.E.; Hasanein, A.M.; Abu Elnasr, A.E. Responses to COVID-19 in Higher Education: Social Media Usage for Sustaining Formal Academic Communication in Developing Countries. Sustainability 2020, 12, 6520. [CrossRef]

6. Almanthari, A.; Maulina, S.; Bruce, S. Secondary School Mathematics Teachers' Views on E-learning Implementation Barriers during the COVID-19 Pandemic: The Case of Indonesia. Eurasia J. Math. Sci. Technol. Educ. 2020, 16, em1860.

7. Kerres, M. Against All Odds: Education in Germany Coping with Covid-19. Postdigital Sci. Educ. 2020, 2, 690-694. [CrossRef] 
8. Wang, C.J.; Ng, C.Y.; Brook, R.H. Response to COVID-19 in Taiwan: Big data analytics, new technology, and proactive testing. JAMA 2020, 323, 1341-1342. [CrossRef]

9. Omar, A.; Kalulu, D.; Alijani, G.S. Management of innovative e-learning environments. Acad. Educ. Leadersh. J. $2011,15,37$.

10. Al-Rahmi, W.M.; Yahaya, N.; Aldraiweesh, A.A.; Alamri, M.M.; Aljarboa, N.A.; Alturki, U.; Aljeraiwi, A.A. Integrating Technology Acceptance Model with Innovation Diffusion Theory: An Empirical Investigation on Students' Intention to Use E-Learning Systems. IEEE Access 2019, 7, 26797-26809. [CrossRef]

11. Al-Maatouk, Q.; Othman, M.S.; Aldraiweesh, A.; Alturki, U.; Al-Rahmi, W.M.; Aljeraiwi, A.A. Task-Technology Fit and Technology Acceptance Model Application to Structure and Evaluate the Adoption of Social Media in Academia. IEEE Access 2020, 8, 78427-78440. [CrossRef]

12. UNESCO Covid-19 Educational Disruption and Response. 2020. Available online: https://en.unesco.org/covid19/ educationresponse (accessed on 11 November 2020).

13. Abbasi, S.; Ayoob, T.; Malik, A.; Memon, S.I. Perceptions of students regarding E-learning during Covid-19 at a private medical college. Pak. J. Med. Sci. 2020, 36, S57. [CrossRef] [PubMed]

14. Alias, N.A.; Zainuddin, A.M. Innovation for better teaching and learning: Adopting the Learning Management System. Malays. Online J. Instr. Technol. 2005, 2, 27-40.

15. Zwain, A.A.A. Technological innovativeness and information quality as neoteric predictors of users' acceptance of Learning Management System: An expansion of UTAUT2. Interact. Technol. Smart Educ. 2019, 16, 239-254. [CrossRef]

16. Ain, N.; Kaur, K.; Waheed, M. The influence of learning value on Learning Management System use: An extension of UTAUT2. Inf. Dev. 2016, 32, 1306-1321. [CrossRef]

17. Lonn, S.; Teasley, S.D.; Krumm, A.E. Who needs to do what where?: Using Learning Management Systems on residential vs. commuter campuses. Comput. Educ. 2011, 56, 642-649. [CrossRef]

18. Waheed, M.; Kaur, K.; Ain, N.; Hussain, N. Perceived learning outcomes from Moodle: An empirical study of intrinsic and extrinsic motivating factors. Inf. Dev. 2016, 32, 1001-1013. [CrossRef]

19. Matar, N.; Hunaiti, Z.; Halling, S.; Matar, S. E-Learning acceptance and challenges in the Arab region. In ICT Acceptance, Investment and Organization: Cultural Practices and Values in the Arab World; Abdallah, S., Ahmad, A.F., Eds.; IGI Global: Hershey, Pennsylvania, 2011; pp. 184-200.

20. Decman, M. Modeling the acceptance of e-learning in mandatory environments of higher education: The influence of previous education and gender. Comput. Hum. Behav. 2015, 49, 272-281. [CrossRef]

21. Ma, W.; Yuen, A. E-learning system acceptance and usage pattern. In Technology Acceptance in Education; Teo, T., Ed.; Brill Sense, 2011; pp. 201-216. Available online: https:/ / www.researchgate.net/publication/291068987_E-Learning_System_Acceptance_ and_Usage_Pattern (accessed on 1 July 2021).

22. Vankatesh, V.; Davis, F.D. A model of the antecedents of perceived ease of use: Development and test. Decis. Sci. 1996, $27,451-481$. [CrossRef]

23. Alenazy, W.M.; Al-Rahmi, W.M.; Khan, M.S. Validation of TAM Model on Social Media Use for Collaborative Learning to Enhance Collaborative Authoring. IEEE Access 2019, 7, 71550-71562. [CrossRef]

24. Al-Rahmi, W.M.; Yahaya, N.; Alturki, U.; Alrobai, A.; Aldraiweesh, A.A.; Omar Alsayed, A.; Kamin, Y.B. Social media-based collaborative learning: The effect on learning success with the moderating role of cyberstalking and cyberbullying. Interact. Learn. Environ. 2020, 3, 1-14. [CrossRef]

25. Islam, A.K.M.N. Investigating LMS usage outcomes in the university context. Comput. Educ. 2013, 69, 387-399. [CrossRef]

26. Liaw, S.S.; Huang, H.M. Investigating learner attitudes toward e-books as learning tools: Based on the activity theory approach. Interact. Learn. Environ. 2014, 24, 625-643. [CrossRef]

27. Al-Rahmi, W.M.; Yahaya, N.; Aldraiweesh, A.A.; Alturki, U.; Alamri, M.; Bin Saud, M.S.; Kamin, Y.; Aljeraiwi, A.A.; Alhamed, O.A. Big Data Adoption and Knowledge Management Sharing: An Empirical Investigation on Their Adoption and Sustainability as a Purpose of Education. IEEE Access 2019, 7, 47245-47258. [CrossRef]

28. Diener, E.; Seligman, M.E. Beyond Money: Toward an Economy of Well-Being. Psychol. Sci. Public Interest 2004, 5, 201-265. [CrossRef]

29. Huppert, F.A.; So, T.T. Flourishing Across Europe: Application of a New Conceptual Framework for Defining Well-Being. Soc. Indic. Res. 2013, 110, 837-861. [CrossRef] [PubMed]

30. Scrimin, S.; Moscardino, U.; Altoè, G.; Mason, L. Effects of perceived school well-being and negative emotionality on students' attentional bias for academic stressors. Br. J. Educ. Psychol. 2016, 86, 278-295. [CrossRef]

31. Steptoe, A.; Deaton, A.; Stone, A.A. Psychological wellbeing, health and ageing. Lancet 2015, 385, 640. [CrossRef]

32. Tremayne, M.; Chen, X.; Figur, N.; Huang, J.S. Perceived authority and communication channel: Experiments with instant messaging. Soc. Sci. Comput. Rev. 2008, 26, 178-189. [CrossRef]

33. Aral, S.; Walker, D. Creating Social Contagion Through Viral Product Design: A Randomized Trial of Peer Influence in Networks. Manag. Sci. 2011, 57, 1623-1639. [CrossRef]

34. Turner, J. Social Influence; Open University Press: Milton Keynes, UK, 1991.

35. Eagly, A.H.; Karau, S. Role congruity theory of prejudice toward female leaders. Psychol. Rev. 2002, 109, 573. [CrossRef]

36. Albanesi, C.; Cicognani, E.; Zani, B. Sense of community, civic engagement and social well-being in Italian adolescents. J. Community Appl. Soc. Psychol. 2007, 17, 387-406. [CrossRef] 
37. Lord, A.T.; DeZoort, F.T. The impact of commitment and moral reasoning on auditors' responses to social influence pressure. Account. Organ. Soc. 2001, 26, 215-235. [CrossRef]

38. Carey, J.C. Development of an instrument to measure rapport between college roommates. J. Coll. Stud. Pers. 1986, $27,269-273$.

39. Frisby, B.N.; Martin, M.M. Instructor-student and student-student rapport in the classroom. Commun. Educ. 2010, 59, 146-164. [CrossRef]

40. Ryan, R.G.; Wilson, J.H.; Pugh, J.L. Psychometric Characteristics of the Professor-Student Rapport Scale. Teach. Psychol. 2011, 38, 135-141. [CrossRef]

41. Frisby, B.N.; Mansson, D.H.; Kaufmann, R. The Cognitive Learning Measure: A Three-Study Examination of Validity. Commun. Methods Meas. 2014, 8, 163-176. [CrossRef]

42. Ryan, R.M.; Deci, E.L. Self-determination theory and the facilitation of intrinsic motivation, social development, and well-being. Am. Psychol. 2000, 55, 68-78. [CrossRef]

43. Skinner, E.A.; Belmont, M.J. Motivation in the classroom: Reciprocal effects of teacher behavior and student engagement across the school year. J. Educ. Psychol. 1993, 85, 571-581. [CrossRef]

44. Aelterman, A.; Engels, N.; Van Petegem, K.; Verhaeghe, J.P. The well? being of teachers in Flanders: The importance of a supportive school culture. Educ. Stud. 2007, 33, 285-297. [CrossRef]

45. Davis, F.D. Perceived usefulness, perceived ease of use, and user acceptance of information technology. MIS Q. 1989, 13, 319-340. [CrossRef]

46. Chen, H.R.; Tseng, H.F. Factors that influence acceptance of web-based LMSs for the in-service education of junior high school teachers in Taiwan. Eval. Program. Plan. 2012, 35, 398-406. [CrossRef] [PubMed]

47. Alamri, M.M.; Almaiah, M.A.; Al-Rahmi, W.M. The Role of Compatibility and Task-Technology Fit (TTF): On Social Networking Applications (SNAs) Usage as Sustainability in Higher Education. IEEE Access 2020, 8, 161668-161681. [CrossRef]

48. Alhussain, T.; Al-Rahmi, W.M.; Othman, M.S. Students' Perceptions of Social Networks Platforms use in Higher Education: A Qualitative Research. Int. J. Adv. Trends Comput. Sci. Eng. 2020, 9, 2589-2603. [CrossRef]

49. Pikkarainen, T.; Pikkarainen, K.; Karjaluoto, H.; Pahnila, S. Consumer acceptance of online banking: An extension of the technology acceptance model. Internet Res. 2004, 14, 224-235. [CrossRef]

50. Al-Rahmi, W.M.; Alzahrani, A.I.; Yahaya, N.; Alalwan, N.; Kamin, Y. Digital Communication: Information and Communication Technology (ICT) Usage for Education Sustainability. Sustainability 2020, 12, 5052. [CrossRef]

51. Alkhalaf, S.; Drew, S.; Alghamdi, R.; Alfarraj, O. LMS on higher education institutions in KSA: Attitudes and perceptions of faculty members. Procedia-Soc. Behav. Sci. 2012, 47, 1199-1205. [CrossRef]

52. Chow, M.; Herold, D.K.; Choo, T.M.; Chan, K. Extending the technology acceptance model to explore the intention to use Second Life for enhancing healthcare education. Comput. Educ. 2012, 59, 1136-1144. [CrossRef]

53. Abuhassna, H.; Al-Rahmi, W.M.; Yahya, N.; Zakaria, M.A.Z.M.; Kosnin, A.B.M.; Darwish, M. Development of a new model on utilizing online learning platforms to improve students' academic achievements and satisfaction. Int. J. Educ. Technol. High. Educ. 2020, 17, 1-23. [CrossRef]

54. Venkatesh, V.; Morris, M.G.; Davis, G.B.; Davis, F.D. User acceptance of information technology: Toward a unified view. MIS Q. 2003, 27, 425-478. [CrossRef]

55. Hu, P.J.-H.; Hui, W. Examining the role of learning engagement in technology-mediated learning and its effects on learning effectiveness and satisfaction. Decis. Support Syst. 2012, 53, 782-792. [CrossRef]

56. Lam, S.-F.; Wong, B.P.; Yang, H.; Liu, Y. Understanding student engagement with a contextual model. In Handbook of Research on Student Engagement; Christenson, S., Reschly, A.L., Wylie, C., Eds.; Springer: New York, NY, USA, 2012; pp. $403-419$.

57. Carini, R.M.; Kuh, G.D.; Klein, S.P. Student engagement and student learning: Testing the linkages. Res. High. Educ. 2006, 47, 1-32. [CrossRef]

58. Klem, A.M.; Connell, J.P. Relationships Matter: Linking Teacher Support to Student Engagement and Achievement. J. Sch. Heal. 2004, 74, 262-273. [CrossRef] [PubMed]

59. Deater-Deckard, K.; Chang, M.; Evans, M.E. Engagement States and Learning from Educational Games. New Dir. Child Adolesc. Dev. 2013, 2013, 21-30. [CrossRef] [PubMed]

60. Rodgers, T.; Ghosh, D. Measuring the determinants of quality in UK higher education: A multinomial logit approach. Qual. Assur. Educ. 2001, 9, 121-126. [CrossRef]

61. Davies, D.; Graff, M. Performance in e-learning: Online participation and student grades. Br. J. Educ. Technol. 2005, 36, 657-663. [CrossRef]

62. Arbaugh, J. How Classroom Environment and Student Engagement Affect Learning in Internet-based MBA Courses. Bus. Commun. Q. 2000, 63, 9-26. [CrossRef]

63. Krejcie, R.V.; Morgan, D.W. Determining Sample Size for Research Activities. Educ. Psychol. Meas. 1970, 30, 607-610. [CrossRef]

64. Hair, J.F.; Risher, J.; Sarstedt, M.; Ringle, C.M. When to use and how to report the results of PLS-SEM. Eur. Bus. Rev. 2019, 31, 2-24. [CrossRef]

65. Keyes, C.L.M. Mental Illness and/or Mental Health? Investigating Axioms of the Complete State Model of Health. J. Consult. Clin. Psychol. 2005, 73, 539-548. [CrossRef]

66. Eckles, R.E.; Meslin, E.M.; Gaffney, M.; Helft, P.R. Medical Ethics Education: Where Are We? Where Should We Be Going? A Review. Acad. Med. 2005, 80, 1143-1152. [CrossRef] 
67. $\mathrm{Ng}$, C.S.-P. Intention to purchase on social commerce websites across cultures: A cross-regional study. Inf. Manag. 2013, 50, 609-620. [CrossRef]

68. Ratna, P.A.; Mehra, S. Exploring the acceptance for e-learning using technology acceptance model among university students in India. Int. J. Process. Manag. Benchmarking 2015, 5, 194-210. [CrossRef]

69. Ramírez-Correa, P.E.; Arenas-Gaitán, J.; Rondán-Cataluña, F.J. Gender and Acceptance of E-Learning: A Multi-Group Analysis Based on a Structural Equation Model among College Students in Chile and Spain. PLoS ONE 2015, 10, e0140460. [CrossRef]

70. Muhaimin, H.; Mukminin, A.; Pratama, R.; Asrial, H. Predicting factors affecting intention to use Web 2.0 in learning: Evidence from science education. J. Balt. Sci. Educ. 2019, 18, 595. [CrossRef]

71. Nikou, S.A.; Economides, A.A. Mobile-based assessment: Investigating the factors that influence behavioral intention to use. Comput. Educ. 2017, 109, 56-73. [CrossRef]

72. Mohammadi, H. Investigating users' perspectives on e-learning: An integration of TAM and IS success model. Comput. Hum. Behav. 2015, 45, 359-374. [CrossRef]

73. Zhang, S.; Zhao, J.; Tan, W. Extending TAM for online learning systems: An intrinsic motivation perspective. Tsinghua Sci. Technol. 2008, 13, 312-317. [CrossRef]

74. Buabeng-Andoh, C.; Yaokumah, W.; Tarhini, A. Investigating students' intentions to use ICT: A comparison of theoretical models. Educ. Inf. Technol. 2018, 24, 643-660. [CrossRef]

75. Teo, T.; Sang, G.; Mei, B.; Hoi, C.K.W. Investigating pre-service teachers' acceptance of Web 2.0 technologies in their future teaching: A Chinese perspective. Interact. Learn. Environ. 2018, 27, 530-546. [CrossRef]

76. Alamri, M.M.; Almaiah, M.A.; Al-Rahmi, W.M. Social Media Applications Affecting Students' Academic Performance: A Model Developed for Sustainability in Higher Education. Sustainability 2020, 12, 6471. [CrossRef]

77. Teo, T. Is there an attitude problem? Reconsidering the role of attitude in the TAM. Br. J. Educ. Technol. 2009, 40, 1139-1141. [CrossRef]

78. Al-Rahmi, W.M.; Othman, M.S.; Yusuf, L.M. Effect of engagement and collaborative learning on satisfaction through the use of social media on Malaysian higher education. Res. J. Appl. Sci. Eng. Tech. 2015, 9, 1132-1142. [CrossRef]

79. Naveed, Q.N.; Alam, M.M.; Tairan, N. Structural Equation Modeling for Mobile Learning Acceptance by University Students: An Empirical Study. Sustainability 2020, 12, 8618. [CrossRef]

80. Zhang, T.; Shaikh, Z.A.; Yumashev, A.V.; Chłąd, M. Applied Model of E-Learning in the Framework of Education for Sustainable Development. Sustainability 2020, 12, 6420. [CrossRef]

81. Stuss, M.M.; Szczepańska-Woszczyna, K.; Makieła, Z.J. Competences of graduates of higher education business studies in labor market I (results of pilot cross-border research project in Poland and Slovakia). Sustainability 2019, 11, 4988. [CrossRef]

82. Alam, M.M.; Ahmad, N.; Naveed, Q.N.; Patel, A.; Abohashrh, M.; Khaleel, M.A. E-Learning Services to Achieve Sustainable Learning and Academic Performance: An Empirical Study. Sustainability 2021, 13, 2653. [CrossRef]

83. Murphy, M.P. COVID-19 and emergency eLearning: Consequences of the securitization of higher education for post-pandemic pedagogy. Contemp. Secur. Policy 2020, 41, 492-505. [CrossRef]

84. Anthony, A.B.; Patravanich, S. The technology principal: To be or not to be? J. Cases Educ. Leadersh. 2014, 17, 3-19. [CrossRef]

85. Waxman, H.C.; Boriack, A.W.; Lee, Y.; MacNeil, A. Principals' Perceptions of the Importance of Technology in Schools. Contemp. Educ. Technol. 2013, 4, 187-196. [CrossRef]

86. Sun, P.C.; Tsai, R.J.; Finger, G.; Chen, Y.Y.; Yeh, D. What drives a successful e-Learning? An empirical investigation of the critical factors influencing learner satisfaction. Comput. Educ. 2008, 50, 1183-1202. [CrossRef]

87. Varier, D.; Dumke, E.K.; Abrams, L.M.; Conklin, S.B.; Barnes, J.S.; Hoover, N.R. Potential of one-to-one technologies in the classroom: Teachers and students weigh in. Educ. Technol. Res. Dev. 2017, 65, 967-992. [CrossRef] 